\title{
Research on Problems and Countermeasures of Financial Management in Modern Agricultural Enterprises
}

\author{
Aihui Zhang \\ Xi’an International University, Shaanxi, Xi’an, 710077
} Keywords: modern agricultural enterprise; financial management; existing problems;
countermeasures and suggestions

\begin{abstract}
Modern agricultural enterprises are established based on a modern enterprise system. They engage in crop farming or aquaculture, or use them as a basis for comprehensive management of agriculture, industry, and business, and implement independent accounting and economic organizations with legal status. This paper analyzes the problems existing in the financial management of China's agricultural enterprises at the present stage, discusses the causes of the problems, and proposes countermeasures and suggestions for solving the problems.
\end{abstract}

\section{Introduction}

Agriculture is the foundation of China's national economy. With the development of market economy and the deepening of economic system reform, our country's agricultural enterprises implement independent management and self-financing under the premise of clear property rights, clear rights and responsibilities, separation of government and enterprise, and management science. As an important part of the economic management of agricultural enterprises, financial management plays an increasingly important role in the financing, operation, and distribution of a series of financial activities, although some agricultural enterprises and institutions in China have made efforts to strengthen financial management. A lot of work has also achieved good results, but we have also noticed that many agricultural enterprises have neglected financial management, resulting in serious waste, rising costs, and low efficiency. Therefore, establishing and improving the financial management of modern agricultural enterprises is crucial for the survival of agricultural enterprises.

\section{Characteristics of Agricultural Enterprises and Their Accounting}

Land is an important production material for agricultural production and is the basis for agricultural production; agricultural production has obvious seasonality and regionality, labor time and production time are inconsistent, and the production cycle is long; some labor data and labor objects in agricultural production can mutually In conversion, some products can be re-invested as production materials; there is an interdependence and mutual promotion relationship between planting and aquaculture, which requires that management must be adapted to it. In general, the business principles of one industry as the main business, diversified operations, and all-round development are generally adopted. The agricultural production not only implements one-industry-based operation and diversified operations, but also implements joint production contracting, unified sub-distribution, and double-level management in management. The system.

Accounting content diversity. The operation of agricultural enterprises often involves agriculture, forestry, animal husbandry, deputy fisheries, fisheries, engineering, and other industries. This requires that accounting should not only meet the needs of comprehensive corporate management, but also adapt to the characteristics of production and operation in various industries, calculate the cost and financial results of each industry, and assess various non-productive expenses; the complexity of the management system Sex. Agricultural enterprises implement a variety of operations and double-level management systems. For example, state-owned farms have field offices, breakouts, and production teams at various levels. Professional service organizations and 
family farms are also commonly established; rural economic cooperative organizations generally implement farmer household associations. At the same time as contracting production, the production and service organizations for unified management have also been established accordingly; the system of township and village enterprises is more complex and diverse. This will undoubtedly bring complexity to accounting and management systems; flexibility in accounting methods.

\section{Problems in Financial Management of Agricultural Enterprises}

Corporate finance activities mainly include three aspects, namely financing activities, investment activities and distribution activities. With the development of the market economy, financial management has been increasingly valued by more and more companies and has strengthened management in the above three aspects. However, due to the current system is not yet mature and sound, under the current conditions, the financial management of agricultural enterprises in China There are still many problems in China that need urgent solution.

The accounting of agricultural enterprises in China should be adjusted and supplemented in light of the conflicts with the new "Enterprise Accounting System" and specific accounting standards. At present, under the market economy conditions, great changes have taken place in the management system, business model, and scope of business activities of agricultural enterprises. The accounting of agricultural enterprises still implements the Accounting System for Agricultural Enterprises and cannot meet the needs of accounting information users. It can't guarantee the quality of accounting data of agricultural enterprises.

Financial management includes the establishment of an internal management system and the strengthening of accounting and cost management. It is the basis for the implementation of financial management, supervision and decision-making. At present, the basic work of some agricultural enterprises is weak, management is chaotic, leadership is lazy, discipline is slack, work efficiency is not high, and the quality of financial staff is uneven. The financial management institutions are not perfect and it is difficult to adapt to the requirements of the development of the market economy.

Due to various reasons, accounting accounting in various countries has different degrees of distortion of accounting information, and our country's agricultural enterprises are no exception. On the one hand, agricultural production activities are greatly affected by natural conditions. Humans cannot predict and prevent the occurrence of unfavorable natural events. They cannot effectively control and supervise the entire process of agricultural production, and thus cannot guarantee the accounting measurement and recording of agricultural production activities. The accuracy has led to distortion of accounting information. On the other hand, as farmers and family farms of land contractors, under the mode of self-management, they can completely occupy and control the remaining part of the project after completing the contracting task, and reflect the accuracy and distortion of the accounting information of agricultural production activities for each contractor. Interest does not have much interest, and the lack of interest incentive mechanisms further distort accounting information.

Due to the low quality of financial management personnel in agricultural enterprises, many enterprises cannot implement computerized financial management. Many companies do not set up accounts and check the company's operating conditions in strict accordance with the requirements of the national accounting system. At the same time, the company's accounting statements must truly reflect the financial status of its own production and operation results within a certain period of time. It is the basis for management to understand the operation of the company and make scientific decisions. However, many agricultural enterprises lack the necessary supervision and management mechanisms for financial management. The financial departments make false accounts based on their opinions, leading to severe distortion of accounting information, hindering the healthy development of enterprises, and causing the loss of large amounts of state-owned assets.

Some agricultural enterprises do not pay enough attention to the controllable costs because of their low cost awareness, resulting in unnecessary expenditures, which results in high costs, loss of enterprises year by year, and inefficiency of efficiency. In addition, some agricultural enterprises did 
not rationally arrange the capital structure during the use of funds, constantly introduced new projects, blindly introduced, duplicated construction, and the long-term investment scale was too large, resulting in a serious shortage of production and management funds, and the debt burden was getting heavier. Visible, only to strengthen financial management, reduce the various costs, agricultural companies can do a good job.

Finance personnel must first be accountable to the state and protect national assets from infringement. At the same time, however, the performance evaluation and positional appointment and dismissal of accounting personnel are held in the hands of enterprises, and they lack a mechanism for protecting their own interests. For enterprises, for the sake of their own interests, state-owned assets are sometimes damaged, and accounting personnel have to rely on their own survival. However, the contradiction of such interests has inevitably led to many problems in the financial management of agricultural enterprises.

\section{Measures for Formulating Financial Management of Modern Agricultural Enterprises}

With the continuous development and improvement of the market economy, the financial management of agricultural enterprises should proceed from the traditional accounting and accounting reimbursement stages, to the prediction beforehand, the control during the event, and the feedback afterwards. In all aspects of materials, we must give full play to the assessment of accounting forecast, decision-making, budgeting, control, and analysis. Efforts to modernize accounting work require that agribusiness companies must have a group of accounting personnel with new ideas, high quality, and good management. An incentive mechanism should be established to encourage long-term self-learning and to reward those who have achieved excellent results in learning. Regularly organize training and learning so that financial personnel can update and master state tax laws, regulations, and accounting policies in a timely manner to provide practical decisions for agricultural enterprises so as to improve the economic efficiency of enterprises.

Financial management is a means to ensure the normal needs of funds for other elements. Financial management and technology management, production management, procurement management, and quality management must be coordinated to solve the problems in the business, so as to address how to balance development investment, recent profit, and long-term future. Development issues, etc. Excellent financial management should be a balance between the long-term development of agricultural enterprises and the near-term goals, providing financial support for the operations of various departments, and not simply focusing on what financial management, financial management will not be implemented into production, technology, development, and sales. Such specific links do not use the objectives of these specific links as management requirements, and the recent "increasing income and reducing expenditures" from the perspective of the financial department will not be beneficial to the realization of the agricultural business goals.

Distortion of accounting statements is an important issue in agricultural enterprises. To effectively prevent and prevent such phenomena and improve the quality of accounting statements, in addition to determining a reasonable balance between financial personnel's responsibilities and powers and professional qualities, external accounting supervision should be strengthened to standardize accounting. Report audit work. To this end, the mechanism of "separation of three supervisions from one to three trials" should be established. That is, a statement auditing system should be implemented according to law. At the same time, internal supervision, social supervision, and government supervision, as well as the separation of internal auditing, social auditing, and government auditing, should be performed. Among them, the agricultural enterprise should set up an internal audit institution that is independent of the accounting organization and achieve a true auditing effect. For external auditing, relevant agencies should strictly enforce the law to jointly ensure the quality of corporate accounting information and protect state-owned assets from infringement.

Capital is the most important economic resource in economic operation, and it will certainly become the focus of financial management. We will improve the examination and approval 
procedures and strengthen the centralized and unified management of funds. That is, agricultural enterprises should implement a centralized fund examination and approval system, strengthen the penholders' examination and approval, strengthen unified fund management, and establish a minimum fund guarantee system.

Budget management is an important means of controlling expenditures and ensuring the balance of revenues and expenditures. It is an important basic work for financial management. The scope of budget management should be expanded to include all income and expenditure in the unified management of the budget, accurately and comprehensively reflect the overall picture of the income and expenditure of agricultural enterprises, reduce the phenomenon of extra-budgetary expenditures, refine the budget, and decompose them on a layer-by-layer basis to implement each department and each construction link. Implementation status is an important part of the year-end assessment, and rewards and punishments are combined with rewards and penalties; the seriousness of the budget is maintained and the rigidity of the budget is strengthened. Once the prescribed budget is approved, it shall not be arbitrarily changed except in exceptional circumstances.

Financing management and fixed asset management are important components of enterprise asset management. First of all, the lack of liquidity is a common problem in many small and medium-sized agricultural enterprises. This requires companies to establish a good credit image and effective financing. Secondly, for the management of fixed assets, agricultural enterprises should first clarify the reasonable pricing method and strengthen financial Controlling and establishing an internal control system for fixed assets of agricultural enterprises. In addition, in order to make the best use of funds, it should also strive to improve the efficiency of the use of funds, so that the source and use of funds to effectively cooperate; scientific and rational allocation of funds to determine a reasonable ratio of liquidity and fixed funds; Strengthen the management of inventory and accounts receivable.

\section{Acknowledgements}

Fund project: 2016-Shaanxi provincial Department of science and technology plan items (2016JM7009).The comparative mode of rural land mortgage finance operation in Shaanxi based on the mortgaged condition.

\section{References}

[1] Li Jue. Thoughts on Strengthening the Financial Management of Agricultural Enterprises [J]. Chinese Economics and Trade, 2009 (8)

[2] Li Ping. Financial Management and Analysis of Agricultural Enterprises [M]. Beijing: Intellectual Property Publishing House, 2006.

[3] Liu Xingyu. Discussion on problems and countermeasures of financial management in agricultural enterprises [J]. South China Agriculture, 2008(5) 